\title{
Value Added Tax \& Export: the Case of Selected Countries around the World
}

\author{
*Ahmad Jafari samimi, Mehrnoosh Abdolahi \\ Department of Economics, Firoozkooh Branch, Islamic Azad University, Firoozkooh, Iran \\ *jafarisa@yahoo.com
}

\begin{abstract}
The purpose of the present paper is to compare the impact of implementing Value Added Tax on Export of goods and services in selected countries. In this paper, we used four different indices for export; export of goods and services, export of goods and services (BOP), export of goods and services (annual \% growth), export of goods and services (\% of GDP) to investigate the sensitivity to different definitions .To do so, study concentrated on a sample of 140 countries that have applied Value Added Tax in their tax system from 1990 to 2008. Findings of the study based on Mean Difference Statistical Test in a two threeyear periods before and after introduction of VAT. In general, the results show that, in different indices, the impact of VAT on export is positive. Therefore, it is suggested that other countries have not yet introduced the VAT to reform their tax system by introducing the VAT.
\end{abstract}

Keywords: Value-Added Tax (VAT), Export of goods and services Indices, Mean Difference

\section{Introduction and Literature}

Some important economic goals of governments are optimum allocation of resources, fair distribution of income, economic growth, increasing employment, decreasing budget deficit, economic stability, and maintaining the general level of prices-decreasing inflation. Taxes can help the governments to attain these goals as a political tool. In fact, one the main sources of the governments' income is tax that is gotten in different ways. Tax income forms a big portion of the governments' budget. One of these taxes is ValueAdded Tax (VAT). VAT is a multi-level tax that is obtained in different steps of the production-distribution cycle based on a percentage of the value added to the products or services. In fact, this tax is a kind of a multi-level tax on sales that exempts the indirect purchase of goods and services from tax.

Von Siemens introduced and design Value-Added Tax based on financial problems that German faced after the World War II in 1948. Then in 1951, Michael Lure introduced it in France. In the late 1950s the high benefits of this tax was determined and different countries tended to apply it. In 1954 for the first time, France applied VAT as a tax on the consumption goods in production level. In addition, in 1986 could extend it to the retail level. In 1962, EEC recommended the application of this tax to the members of EU and in 1966 assigned them to accept its application. All the members of the Latin American Common Market led by Brazil applied VAT in their tax systems in 1967. In the early 1970s, the Tax Office of IMF1 help South Korea to introduce VAT and this country was the first Asian country that accepted to apply this tax in 1977. Now more than 140 countries use VAT because of its advantages.

VAT can affect on indices of export of goods and services in different aspects. In this system, using consumer value added tax (C-VAT) will provide production but it may decrease the consumption. In this matter producer face to supply surplus and start to export the surplus. By presenting tax, facilities to support investment can provide export. If VAT replace inefficient tax systems, increase in efficiency can effect production positively and will lead to export promotion. In addition, if VAT neutralizes the negative effects of tax on social insurance, it can prevent from decreasing labor supply, can affect the production factors, and will lead to increase the export. In the lump C-VAT can increase the export in most countries. It seems that the substitution of the value-added tax for all other federal taxes, or even for just the existing federal personal income tax, is a policy proposal that all supporters of growth in the private sector relative to the government sector would support (Baird, 1981). VAT in products level in Indonesia in the first year of accomplishment, led to increasing in income up to 45 percent. It is more than the target growth which increased the financial resources to perform the projects in different parts. It's surprising that this country is famous for having a weak tax management (Jenkins, 1989). The VAT reform, accompanied by a cut in transfers to the poor, has no effect on capital accumulation if the rich and poor have the same rate of time preference. It decreases (increases) capital accumulation If the rich has a higher (lower) rate of time

1- International Monetary Fund 
preference; and increases the utility of the rich and decreases the utility of the poor(Lin, 2007) the European Community adopted the VAT because it was a sales tax that could be identified precisely on exports and imports. It could be rebated entirely on exports by using a zero rate (the credit for taxes on purchases against a zero tax liability on the export sale ensures the exporter is compensated for all VAT levied on earlier stages of production) (Tait, 1996).

Kulis and Miljenovic (1997), showed the negative effect of the multiplicity of VAT rates on the income obtained through this tax. Also they showed that the VAT base in this country from 1994 to 1997 was 50 to 58 percent of GDP. In a study, IMF (2001) recorded a number of empirical rules about VAT;

- The countries that performed VAT have a more per capita GDP level and are less dependent on the international trade.

- Income and economic freedom have a positive relationship with the proportion of the taxes on GDP.

Ministry of Commerce and Finance of Iran studied the problems of the current tax system of Iran and generally the theoretical analysis of the VAT system and its effect on the micro and macro-economic variables and the advantages and disadvantages of VAT system. The experiences of some developing countries such as Indonesia, South Korea, Brazil and Mexico were used and it was resulted that the implement of VAT simplifies reaching the main goal of the tax system that is to increase the tax income. Each percent of VAT produces a net income of 0.4 percent of GDP. In 2005, the U.S. GDP totaled 12.5 trillion dollars. In this year, each percent of VAT rate increases the net income up to 50 billion dollars.

According to Gale and Steuerle, using the VAT in the U.S. has produced an income equal to 250 billion dollars (Gale and Steuerle, 2005). VAT is feasible only as a self assessed tax that substitutes for effective risk-based approaches within a self assessment environment cannot be expected to provide sustainable solutions to compliance problems related to VAT refunds (Harrison and Russell, 2005). The sign of the revenue impact is generally ambiguous, but most countries that have adopted a VAT seem to have gained a more effective tax instrument (Keen and Lockwood, 2007). Worsening (improvement) in the VAT Cefficiency is driven by shifts in consumption patterns and changes in tax evasion during contractions (expansions) (Sancak, Velloso, \& Xing 2010).

\section{Research Methodology}

This research examines the effects of VAT on four indices of export using statistical method and SPSS software. The statistical source of data is WDI ${ }^{2}$ published by the World Bank annually. In this research we use the Means Difference Test in countries that applied VAT. In the Means Difference Test according to export data for 3 years before and 3 years after applying VAT. If we want to compare the mean of two periods before and after applying VAT as two populations, the two following method can compare the two means:

$\sigma_{1}^{2}, \sigma_{2}^{2}$ : Population variances respectively

$\mu_{1}$ : the average rates of export in the years before applying VAT.

$\mu_{2}$ : The average rates of export in the years after applying VAT.

The means test is as follows:

$\mathrm{H}_{0}: \mu_{1}-\mu_{2}=0$

$\mathrm{H}_{1}: \mu_{1}-\mu_{2}<0$

Or

$\mathrm{H}_{0}: \mu_{1}=\mu_{2}$

$\mathrm{H}_{1}: \mu_{1}<\mu_{2}$

If the population variances are assumed to be equal $\sigma_{1}{ }^{2}=\sigma_{2}{ }^{2}$, t-statistic (T) is calculated as follows:

$$
T=\frac{\left(x_{1}-x_{2}\right)-0}{s_{p} \sqrt{\left(\frac{1}{m_{1}}\right)+\left(\frac{1}{m_{2}}\right)}}
$$

2- World Development Indicators 
$\mathrm{X}_{1}$ : The mean of the first sample

$\mathrm{X}_{2}$ : The mean of the second sample

$\mathrm{S}_{\mathrm{p}}$ : The standard error

$\mathrm{n}_{1}$ : The number of observations of the first sample

$\mathrm{n}_{2}$ : The number of observations of the second sample

The specific t-distribution that serves as the reference distribution for the t-statistic depends on the "degrees of freedom" $(V)$ of the test statistic. The degrees of freedom that define the specific t-distribution for this straightforward case is given by

$$
\mathrm{V}=\mathrm{n}_{1}+\mathrm{n}_{2}-2
$$

If the population variances are not assumed to be equal $\left(\sigma_{1}^{2} \neq \sigma_{2}^{2}\right), \mathrm{t}$-statistic (T) is calculated as follows:

$T=\frac{\left(x_{1}-x_{2}\right)-0}{\sqrt{\left(\frac{s_{1}^{2}}{m_{1}}\right)+\left(\frac{s_{2}^{2}}{n_{2}}\right)}}$

$\mathrm{X}_{1}$ : The mean of the first sample

$\mathrm{X}_{2}$ : The mean of the second sample

$\mathrm{S}_{1}$ : The standard deviation of the first sample

$\mathrm{S}_{2}$ : The standard deviation of the second sample

$\mathrm{n}_{1}$ : The number of observations of the first sample

$\mathrm{n}_{2}$ : The number of observations of the second sample

In this more complicated case, the degrees of freedom $(V)$ is given by

$V=\frac{\left(\frac{s_{1}^{2}}{n_{1}}+\frac{s_{2}^{2}}{n_{2}}\right)^{2}}{\frac{\left(\frac{s_{1}^{2}}{n_{1}}\right)^{2}}{n_{1}-1}+\frac{\left(\frac{s_{2}^{2}}{n_{2}}\right)^{2}}{n_{2}-1}}$

We obtain $t$-statistic $\left(t_{\alpha}\right)$ for 5 percent significance level by using of the $t$-statistic table. Considering to the unilateral this test, the condition of acceptance $\mathrm{H}_{0}$, is $\mathrm{T}<\mathrm{t}_{\alpha}$. In this research if Hypothesis $\mathrm{H}_{0}$ be accepted, we deduce that applying VAT has no effect on export and if Hypothesis $\mathrm{H}_{0}$ Be rejected, then applying VAT on export has been effective.

\section{Results}

Comparing the indices of export before and after from applying VAT, in table (1), (3), (5), (7) hypothesis $\mu_{1}>\mu_{2}$ and in table (2), (4), (6), (8) hypothesis $\mu_{1}<\mu_{2}$ is accepted. According to the data tables below, Be determined that Probability of rejection hypothesis $\mathrm{H}_{0}$ in analyzed countries were different. This test has done for export in these countries since 1990 - 2008.

Table 1: Mean Difference of export of goods and services before and after applying VAT $\left(\mu_{1}>\mu_{2}\right)$

\begin{tabular}{ccccc}
\hline country & $\begin{array}{c}\text { mean difference of export of } \\
\text { goods and services before and } \\
\text { after applying VAT }\end{array}$ & $\begin{array}{c}\text { t- } \\
\text { statistic }\end{array}$ & $\begin{array}{c}\text { Sig(2- } \\
\text { tailed) }\end{array}$ & Test Results and Probability \\
\hline Cape Verde & $2.51783 \mathrm{E} 7$ & 12.117 & 0.007 & $\mathrm{H}_{0}$ rejected with $99 \%$ probability \\
Chad & $5.12360 \mathrm{E} 7$ & 4.156 & 0.053 & $\mathrm{H}_{0}$ rejected with $95 \%$ probability \\
\hline
\end{tabular}

Source: Researcher calculations using SPSS software, ( $H_{0}$ rejected with more than 90\% probability) 
Table 2: Mean Difference of export of goods and services before and after applying VAT $\left(\mu_{1}<\mu_{2}\right)$

\begin{tabular}{ccccc}
\hline country & $\begin{array}{c}\text { mean difference of } \\
\text { export of goods and } \\
\text { services before and } \\
\text { after applying VAT }\end{array}$ & t-statistic & $\begin{array}{c}\text { Sig(2- } \\
\text { tailed) }\end{array}$ & Test Results and Probability \\
\hline Cambodia & $-7.72969 \mathrm{E} 8$ & -4.377 & 0.048 & $\mathrm{H}_{0}$ rejected with $95 \%$ probability \\
China & $-6.70934 \mathrm{E} 10$ & -14.830 & 0.005 & $\mathrm{H}_{0}$ rejected with $99 \%$ probability \\
Czech Republic & $-7.46549 \mathrm{E} 9$ & -3.114 & 0.089 & $\mathrm{H}_{0}$ rejected with $91 \%$ probability \\
Finland & $-1.53878 \mathrm{E} 10$ & -3.754 & 0.064 & $\mathrm{H}_{0}$ rejected with $94 \%$ probability \\
Lebanon & $-1.05602 \mathrm{E} 9$ & -3.623 & 0.068 & $\mathrm{H}_{0}$ rejected with $93 \%$ probability \\
Lesotho & $-4.32845 \mathrm{E} 8$ & -2.989 & 0.096 & $\mathrm{H}_{0}$ rejected with $90 \%$ probability \\
Madagascar & $-2.48292 \mathrm{E} 8$ & -6.565 & 0.022 & $\mathrm{H}_{0}$ rejected with $98 \%$ probability \\
Malta & $-4.29076 \mathrm{E} 8$ & -3.861 & 0.061 & $\mathrm{H}_{0}$ rejected with $94 \%$ probability \\
Mauritania & $-9.15245 \mathrm{E} 7$ & -3.927 & 0.059 & $\mathrm{H}_{0}$ rejected with $94 \%$ probability \\
Paraguay & $-1.87837 \mathrm{E} 9$ & -2.964 & 0.097 & $\mathrm{H}_{0}$ rejected with $90 \%$ probability \\
Serbia & $-3.02038 \mathrm{E} 9$ & -7.665 & 0.017 & $\mathrm{H}_{0}$ rejected with $98 \%$ probability \\
Slovak Republic & $-5.38056 \mathrm{E} 9$ & -12.313 & 0.007 & $\mathrm{H}_{0}$ rejected with $99 \%$ probability \\
Sri Lanka & $-8.79553 \mathrm{E} 8$ & -7.745 & 0.016 & $\mathrm{H}_{0}$ rejected with $98 \%$ probability \\
Sudan & $-1.13092 \mathrm{E} 9$ & -12.480 & 0.006 & $\mathrm{H}_{0}$ rejected with $99 \%$ probability \\
Switzerland & $-1.78099 \mathrm{E} 10$ & -3.807 & 0.063 & $\mathrm{H}_{0}$ rejected with $94 \%$ probability \\
Vietnam & $-5.16225 \mathrm{E} 9$ & -11.371 & 0.008 & $\mathrm{H}_{0}$ rejected with $99 \%$ probability \\
\hline
\end{tabular}

Source: Researcher calculations using SPSS software, (Ho rejected with more than 90\% probability)

Table 3: Mean Difference of export of goods and services (BOP) before and after applying VAT $\left(\mu_{1}>\mu_{2}\right)$

\begin{tabular}{ccccc}
\hline country & $\begin{array}{c}\text { mean difference of } \\
\text { export of goods and } \\
\text { services(BOP) before } \\
\text { and after app lying VAT }\end{array}$ & t-statistic & $\begin{array}{c}\text { Sig(2- } \\
\text { tailed) }\end{array}$ & Test Results and Probability \\
\hline Namibia & $1.77576 \mathrm{E} 8$ & 22.191 & 0.002 & $\begin{array}{c}\mathrm{H}_{0} \text { rejected with } 99 \% \\
\text { probability }\end{array}$ \\
\hline
\end{tabular}

Source: Researcher calculations using SPSS software (Ho rejected with more than 90 percent probability)

Table 4: Mean Difference of export of goods and services (BOP) before and after applying VAT $\underline{\left(\mu_{1}<\mu_{2}\right)}$

\begin{tabular}{|c|c|c|c|c|}
\hline country & $\begin{array}{c}\text { mean difference of } \\
\text { export of goods and } \\
\text { services (BOP) before } \\
\text { and after applying VAT }\end{array}$ & $\begin{array}{c}\mathrm{t}- \\
\text { statistic }\end{array}$ & Sig(2-tailed) & Test Results and Probability \\
\hline Barbados* & $-1.42600 \mathrm{E} 8$ & -3.677 & 0.067 & $\mathrm{H}_{0}$ rejected with $93 \%$ probability \\
\hline Bulgaria & $-1.38773 E 9$ & -6.902 & 0.020 & $\mathrm{H}_{0}$ rejected with $98 \%$ probability \\
\hline Cambodia & $-8.87826 \mathrm{E} 8$ & -6.106 & 0.026 & $\mathrm{H}_{0}$ rejected with $97 \%$ probability \\
\hline Cape Verde & $-1.71919 \mathrm{E} 8$ & -6.309 & 0.024 & $\mathrm{H}_{0}$ rejected with $98 \%$ probability \\
\hline China & $-6.88440 \mathrm{E} 10$ & -7.559 & 0.017 & $\mathrm{H}_{0}$ rejected with $98 \%$ probability \\
\hline Ethiopia & $-6.11616 \mathrm{E} 8$ & -3.420 & 0.076 & $\mathrm{H}_{0}$ rejected with $92 \%$ probability \\
\hline Finland & $-1.57472 \mathrm{E} 10$ & -4.153 & 0.053 & $\mathrm{H}_{0}$ rejected with $95 \%$ probability \\
\hline Gabon & $-6.49853 E 8$ & -3.783 & 0.063 & $\mathrm{H}_{0}$ rejected with $94 \%$ probability \\
\hline Ghana & $-8.27380 \mathrm{E} 8$ & -13.281 & 0.006 & $\mathrm{H}_{0}$ rejected with $99 \%$ probability \\
\hline Lesotho & $-3.47080 \mathrm{E} 8$ & -6.026 & 0.026 & $\mathrm{H}_{0}$ rejected with $97 \%$ probability \\
\hline Madagascar & $-2.33775 E 8$ & -7.274 & 0.018 & $\mathrm{H}_{0}$ rejected with $98 \%$ probability \\
\hline Malta & $-3.92242 \mathrm{E} 8$ & -3.295 & 0.081 & $\mathrm{H}_{0}$ rejected with $92 \%$ probability \\
\hline Mauritania & $-6.58177 \mathrm{E} 7$ & -3.937 & 0.059 & $\mathrm{H}_{0}$ rejected with $94 \%$ probability \\
\hline Paraguay & $-1.52660 \mathrm{E} 9$ & -3.141 & 0.088 & $\mathrm{H}_{0}$ rejected with $91 \%$ probability \\
\hline Samoa & $-2.14337 \mathrm{E} 7$ & -3.133 & 0.089 & $\mathrm{H}_{0}$ rejected with $91 \%$ probability \\
\hline Singapore & $-6.41200 \mathrm{E} 10$ & -6.967 & 0.020 & $\mathrm{H}_{0}$ rejected with $98 \%$ probability \\
\hline Sri Lanka & $-8.90494 \mathrm{E} 8$ & -7.521 & 0.017 & $\mathrm{H}_{0}$ rejected with $98 \%$ probability \\
\hline Sudan & $-1.17659 \mathrm{E} 9$ & -31.346 & 0.001 & $\mathrm{H}_{0}$ rejected with $99 \%$ probability \\
\hline Switzerland & $-2.07396 \mathrm{E} 10$ & -7.071 & 0.019 & $\mathrm{H}_{0}$ rejected with $98 \%$ probability \\
\hline Vanuatu & $-2.97372 \mathrm{E} 7$ & -4.784 & 0.041 & $\mathrm{H}_{0}$ rejected with $96 \%$ probability \\
\hline Vietnam & $-5.27667 \mathrm{E} 9$ & -13.509 & 0.005 & $\mathrm{H}_{0}$ rejected with $99 \%$ probability \\
\hline
\end{tabular}


Table 5: Mean Difference of export of goods and services (\% of GDP) before and after applying VAT $\underline{\left(\mu_{1}>\mu_{2}\right)}$

\begin{tabular}{ccccc}
\hline country & $\begin{array}{c}\text { Mean difference of export } \\
\text { of goods and services(\% of } \\
\text { GDP) before and after app } \\
\text { lying VAT }\end{array}$ & $\begin{array}{c}\text { t- } \\
\text { statistic }\end{array}$ & $\begin{array}{c}\text { Sig(2- } \\
\text { tailed) }\end{array}$ & Test Results and Probability \\
\hline Cape Verde & $1.38167 \mathrm{E} 1$ & 12.369 & 0.006 & $\mathrm{H}_{0}$ rejected with $99 \%$ probability \\
Chad & 3.70000 & 3.216 & 0.085 & $\mathrm{H}_{0}$ rejected with 91\% probability \\
\hline
\end{tabular}

Source: Researcher calculations using SPSS software (Horejected with more than 90 percent probability)

Table 6: Means Difference of export of goods and services (\% of GDP) before and after applying VAT $\left(\mu_{1}<\mu_{2}\right)$

\begin{tabular}{ccccc}
\hline country & $\begin{array}{c}\text { Mean difference of export } \\
\text { of goods and services (\% of } \\
\text { GDP) before and after } \\
\text { applying VAT }\end{array}$ & $\begin{array}{c}\text { t- } \\
\text { statistic }\end{array}$ & $\begin{array}{c}\text { Sig(2- } \\
\text { tailed) }\end{array}$ & Test Results and Probability \\
\hline Cambodia & $-1.75900 \mathrm{E} 1$ & -9.213 & 0.012 & $\mathrm{H}_{0}$ rejected with $99 \%$ probability \\
Ethiopia & -2.23000 & -4.608 & 0.044 & $\mathrm{H}_{0}$ rejected with $96 \%$ probability \\
Finland & -9.56667 & -4.376 & 0.048 & $\mathrm{H}_{0}$ rejected with $95 \%$ probability \\
Lebanon & -3.02000 & -4.106 & 0.05 & $\mathrm{H}_{0}$ rejected with $95 \%$ probability \\
Sudan & -7.21000 & -5.206 & 0.035 & $\mathrm{H}_{0}$ rejected with $96 \%$ probability \\
Switzerland & -3.05000 & -4.312 & 0.050 & $\mathrm{H}_{0}$ rejected with $95 \%$ probability \\
Vietnam & $-1.02633 \mathrm{E} 1$ & -12.006 & 0.007 & $\mathrm{H}_{0}$ rejected with $99 \%$ probability \\
\hline Source: Researcher calculations using SPSS software $\left(H_{0}\right.$ rejected with more than $90 \%$ probability)
\end{tabular}

Table 7: Mean Difference of export of goods and services (annual \% growth) before and after applying VAT $\left(\mu_{1}>\mu_{2}\right)$

\begin{tabular}{|c|c|c|c|c|}
\hline country & $\begin{array}{l}\text { mean difference of } \\
\text { export of goods and } \\
\text { services(annual \% } \\
\text { growth) before and } \\
\text { after app lying VAT }\end{array}$ & $\begin{array}{c}\mathrm{t}- \\
\text { statistic }\end{array}$ & $\begin{array}{l}\text { Sig(2- } \\
\text { tailed) }\end{array}$ & Test Results and Probability \\
\hline Albania & 1.90000 & 2.936 & 0.099 & $\mathrm{H}_{0}$ rejected with $90 \%$ probability \\
\hline Macedonia & $1.56000 \mathrm{E} 1$ & 3.636 & 0.068 & $\%$ probability \\
\hline \multirow{2}{*}{\multicolumn{5}{|c|}{$\begin{array}{l}\text { Source: Researcher calculations using SPSS software, (Horejected with more than 90\% probability) } \\
\text { Table 8: the results of the Means Difference Test of export of goods and services (annual \% growth } \\
\text { before and after applying VAT }\left(\boldsymbol{\mu}_{1}<\boldsymbol{\mu}_{2}\right)\end{array}$}} \\
\hline & & & & \\
\hline country & $\begin{array}{l}\text { Mean difference of } \\
\text { export of goods and } \\
\text { services (annual \% } \\
\text { growth) before and } \\
\text { after applying VAT }\end{array}$ & $\begin{array}{c}\mathrm{t}- \\
\text { statistic }\end{array}$ & $\begin{array}{l}\text { Sig(2- } \\
\text { tailed) }\end{array}$ & Test Results and Probability \\
\hline Lebanon & -7.60000 & -5.509 & 0.031 & $\mathrm{H}_{0}$ rejected with $97 \%$ probability \\
\hline $\begin{array}{l}\text { Papua New } \\
\text { Guinea }\end{array}$ & $-1.67167 \mathrm{E} 1$ & -2.800 & 0.10 & $\mathrm{H}_{0}$ rejected with $90 \%$ probability \\
\hline Paraguay & -8.62000 & -3.163 & 0.087 & $\mathrm{H}_{0}$ rejected with $91 \%$ probability \\
\hline
\end{tabular}

Source: Researcher calculations using SPSS software, (Horejected with more than 90\% probability)

\section{Findings \& Concluding Remarks}

Our findings can be summarized as the followings;

In tables (1), (2) although in China export of goods and services in three years before performed VAT was about 79 billion dollar, it growth up to 171 billion dollar in three years after using value added taxation. In Sudan in three years before administering VAT minimum of export of goods and services was about 624 million dollar. This minimum level changes to 1 billion dollar among three years after using VAT system. Mauritania has decreasing process of export before performed VAT, that export of goods and services 
falling down from 461 million to 292 million dollar in 3 years. However by using VAT system it growth up to 525 million dollar.

By looking over the tables (3), (4) we can find out that the index of exporting goods and services in BOP in 21 countries has grown up after using Value Added Taxation and rejected the $\mathrm{H}_{0}$ with more than $90 \%$. For example Ghana, Sudan and Vietnam rejecting hypotheses $\mathrm{H}_{0}$ with $99 \%$ probability. The most export of goods and services in selected countries in tables is belonging to Singapore and Switzerland. Singapore part in export in BOP before using VAT was about 96 billion dollar and by using VAT in three years it growth to 121 billion dollar in the first year and 158 and 168 billion dollar in the two next years. However in Finland the export in BOP before performing VAT has negative trend and it fallen down from 28 billion dollar to 27 billion dollar in two years before using VAT, it grows up and changes to positive trend after administering Value Added Taxation and allocated 35 and 48 billion dollar in the first two years. Therefore not only implementing VAT has no neutral effects in export of goods and services in BOP but it can increase this index in most countries

By contemplation, the tables (5), (6) we can find out that the \%age of export of goods and services in GDP in some countries has grow up after using Value Added Taxation. Table (1) shows some countries like Cape Verde and Chad that $\mathrm{H}_{0}$ rejected with more than $95 \%$ probability and VAT has negative effects on this index. Table (2) shows the positive effects of VAT. In three years before performing VAT minimum rate was allocated to Sudan with $5.34 \%$ of export in GDP, and Switzerland allocated the maximum rate and it's about $63.68 \%$. In Sudan after administering, VAT the export growth up to $15.30 \%$ in GDP. Cambodia performing VAT in 1999, the \%age of export in GDP before using VAT has negative trend but by performing VAT its change to positive trend. In some countries like Ethiopia VAT works as stimulant and increase the index.

Looking through the tables (7),(8) we can find out that annual growth rate of export of goods and services in some countries like Lebanon, Papua New Guinea and Paraguay has grow up after using Value Added Taxation and rejected the $\mathrm{H}_{0}$ with more than $90 \%$. During three years before performed VAT, the maximum of annual growth rate of export in Lebanon was about 16.80 but after using VAT it face to $27 \%$ growth of export of goods and services. However in Papua New Guinea the growth rate of export before performing VAT was negative and it was about -16.37, it grows up and changes to positive figure (10.44) after administering Value Added Taxation. One year before performing VAT in Paraguay, growth rate of export was about 6.72 and this figure has an unbelievable growth rate and it changes to 31.53

Comparing the export before and after applying VAT in each countries implementing VAT, using the mean difference test shows, for all these countries the hypothesis $\mathrm{H}_{0}$ is rejected by more than $90 \%$. In other words, in these countries the average of export before and after applying VAT has been different. The results show that it has positive effects on some countries and negative effects on the others. However, comparing the average export of the countries applying VAT other countries it can be said that the effects of VAT on export is positive. Therefore, it is suggested that other countries have not yet introduced the VAT to reform their tax system by introducing the VAT.

\section{Resources}

Baird, C. W. (1981). Proportionality, Justice, and the Value-Added Tax. Cato Journal, 1(2), 405-420.

Gale, G. W. \& Steuerle, E. C. (2005). Tax Policy Solution, retrieved from http://www.brookings.edu/es /research/projects/budget/fiscal sanity/2005chapter5).

Harrison, G. and Russell, K. (2005). VAT Refunds: A Review of Country Experience. IMF Working Paper, No. 218, 1-33.

Jenkins, G. (1989). Tax Reform: Lessons Learned. Development Discussion Paper, No. 281, 120-137.

Keen, M. and Lockwood, B. (2007). The Value-Added Tax: Its Causes and Consequences. IMF Working Paper, No. 183, 548-560.

Kulis, D. \& Miljenovic, Z. (1997). Estimate of Revenues from the Value Added Tax in the Republic of Croatia. Journal of Financijska Praksa, 20(2), 92-108.

Lin, S. (2007). China's Value-Added Tax Reform, Capital Accumulation, and Welfare Implications. China Economic Review, 19, 197-214.

Sancak, C., Velloso, R. \& Xing, J. (2010). Tax Revenue Response to the Business Cycle. IMF Working Paper No. 71, 10-26.

Tait, A. (1996). Value Added Tax, National. Economic Issue, IMF Publication No.25, 422-480. 


\section{Appendix}

Table 1: Mean Difference of export of goods and services before and after applying VAT $\left(\mu_{1}>\mu_{2}\right)$

\begin{tabular}{ccccc}
\hline country & $\begin{array}{c}\text { mean difference of } \\
\text { export of goods and } \\
\text { services before and } \\
\text { after applying VAT }\end{array}$ & $\begin{array}{c}\text { t- } \\
\text { statistic }\end{array}$ & $\begin{array}{c}\text { Sig(2- } \\
\text { tailed) }\end{array}$ & Test Results and Probability \\
\hline Guinea & $5.75779 \mathrm{E} 7$ & 1.651 & 0.241 & $\mathrm{H}_{0}$ rejected with $76 \%$ probability \\
Namibia & $8.28365 \mathrm{E} 7$ & 2.428 & 0.136 & $\mathrm{H}_{0}$ rejected with 86\% probability \\
\hline Source: Researcher calculations using SPSS software, $\left(\mathrm{H}_{0}\right.$ rejected with less than 90\% probability)
\end{tabular}

Table 2: Mean Difference of export goods and services before and after applying VAT $\left(\mu_{1}<\mu_{2}\right)$

\begin{tabular}{ccccc}
\hline country & $\begin{array}{c}\text { Mean difference of } \\
\text { export of goods and } \\
\text { services before and } \\
\text { after applying VAT }\end{array}$ & t-statistic & $\begin{array}{c}\text { Sig(2- } \\
\text { tailed) }\end{array}$ & Test Results and Probability \\
\hline Barbados & $-1.34788 \mathrm{E} 8$ & -2.419 & 0.137 & $\mathrm{H}_{0}$ rejected with 86 \% probability \\
Ethiopia & $-5.16369 \mathrm{E} 8$ & -2.481 & 0.131 & $\mathrm{H}_{0}$ rejected with 87 \% probability \\
Gabon & $-8.26841 \mathrm{E} 8$ & -2.620 & 0.120 & $\mathrm{H}_{0}$ rejected with 88 \% probability \\
Jordan & $-8.47490 \mathrm{E} 8$ & -2.688 & 0.115 & $\mathrm{H}_{0}$ rejected with 88 \% probability \\
Mozambique & $-2.81090 \mathrm{E} 8$ & -2.596 & 0.122 & $\mathrm{H}_{0}$ rejected with 88\% probability \\
Poland & $-6.83728 \mathrm{E} 9$ & -2.421 & 0.137 & $\mathrm{H}_{0}$ rejected with 86\% probability \\
\hline Source: Researcher calculations using SPSS software, (Horejected with less than $90 \%$ probability)
\end{tabular}

Table 3: Mean Difference of export of goods and services (BOP) before and after applying VAT $\left(\mu_{1}>\mu_{2}\right)$

\begin{tabular}{ccccc}
\hline Country & $\begin{array}{c}\text { Mean difference of } \\
\text { export of goods } \\
\text { and services(BOP) } \\
\text { before and after } \\
\text { app lying VAT }\end{array}$ & t-statistic & $\begin{array}{c}\text { Sig(2- } \\
\text { tailed) }\end{array}$ & Test Results and Probability \\
\hline $\begin{array}{c}\text { Papua New } \\
\text { Guinea }\end{array}$ & $3.33514 \mathrm{E} 8$ & 1.413 & 0.293 & $\mathrm{H}_{0}$ rejected with 70\% probability \\
Tanzania & $8.93467 \mathrm{E} 7$ & 0.984 & 0.429 & $\mathrm{H}_{0}$ rejected with 57\% probability \\
\hline
\end{tabular}

Source: Researcher calculations using SPSS software $\left(\mathrm{H}_{0}\right.$ rejected with less than $90 \%$ probability)

Table 4: Mean Difference of export of goods and services (BOP) before and after applying VAT $\left(\mu_{1}<\mu_{2}\right)$

\begin{tabular}{|c|c|c|c|c|}
\hline country & $\begin{array}{l}\text { mean difference of } \\
\text { export of goods } \\
\text { and services (BOP) } \\
\text { before and after } \\
\text { applying VAT }\end{array}$ & t-statistic & $\begin{array}{l}\text { Sig(2- } \\
\text { tailed) }\end{array}$ & Test Results and Probability \\
\hline Guinea & $-6.28733 \mathrm{E} 7$ & -2.363 & 0.142 & $\mathrm{H}_{0}$ rejected with $86 \%$ probability \\
\hline Jordan & $-8.18640 \mathrm{E} 8$ & -2.395 & 0.139 & $\mathrm{H}_{0}$ rejected with $86 \%$ probability \\
\hline Mozambique & $-2.41742 \mathrm{E} 8$ & -2.320 & 0.146 & $\mathrm{H}_{0}$ rejected with $85 \%$ probability \\
\hline Slovenia & $-1.49133 \mathrm{E} 8$ & -2.107 & 0.170 & $\mathrm{H}_{0}$ rejected with $83 \%$ probability \\
\hline
\end{tabular}

Source: Researcher calculations using SPSS software $\left(\mathrm{H}_{0}\right.$ rejected with less than $90 \%$ probability)

Table (5): the results of the Means Difference Test of export of goods and services (\% of GDP) before and after applying VAT $\left(\mu_{1}>\mu_{2}\right)$

\begin{tabular}{ccccc}
\hline country & $\begin{array}{c}\text { Mean difference of export } \\
\text { of goods and services(\% of } \\
\text { GDP) before and after app } \\
\text { lying VAT }\end{array}$ & $\begin{array}{c}\text { t- } \\
\text { statistic }\end{array}$ & $\begin{array}{c}\text { Sig(2- } \\
\text { tailed) }\end{array}$ & Test Results and Probability \\
\hline Barbados & 6.56000 & 2.424 & 0.136 & $\mathrm{H}_{0}$ rejected with 86\% probability \\
Botswana & 4.53333 & 2.406 & 0.138 & $\mathrm{H}_{0}$ rejected with 86\% probability \\
Namibia & 3.87000 & 2.005 & 0.183 & $\mathrm{H}_{0}$ rejected with 82\% probability \\
Vanuatu & 5.21000 & 2.350 & 0.143 & $\mathrm{H}_{0}$ rejected with 86\% probability \\
\hline
\end{tabular}

Source: Researcher calculations using SPSS software $\left(\mathrm{H}_{0}\right.$ rejected with less than $90 \%$ probability) 
Table 6: Mean Difference of export of goods and services (\% of GDP) before and after applying VAT $\left(\mu_{1}<\mu_{2}\right)$

\begin{tabular}{ccccc}
\hline country & $\begin{array}{c}\text { Mean difference of export } \\
\text { of goods and services }(\% \\
\text { of GDP) before and after } \\
\text { applying VAT }\end{array}$ & $\begin{array}{c}\text { t- } \\
\text { statistic }\end{array}$ & $\begin{array}{c}\text { Sig(2- } \\
\text { tailed) }\end{array}$ & Test Results and Probability \\
\hline $\begin{array}{c}\text { Australia } \\
\text { Congo, }\end{array}$ & -1.88000 & -2.651 & 0.118 & $\mathrm{H}_{0}$ rejected with 88\% probability \\
$\begin{array}{c}\text { Dem. Rep. } \\
\text { Nigeria }\end{array}$ & $-1.07467 \mathrm{E} 1$ & -2.738 & 0.112 & $\mathrm{H}_{0}$ rejected with 89\% probability \\
$\begin{array}{c}\text { Papua New } \\
\text { Guinea }\end{array}$ & -2.53667 & -2.428 & 0.136 & $\mathrm{H}_{0}$ rejected with 86\% probability \\
Paraguay & $-1.06767 \mathrm{E} 1$ & -2.772 & 0.109 & $\mathrm{H}_{0}$ rejected with 89\% probability \\
\hline
\end{tabular}

Source: Researcher calculations using SPSS software ( $\mathrm{H}_{0}$ rejected with less than $90 \%$ probability)

Table 7: Mean Difference of export of goods and services (annual \% growth) before and after applying $\operatorname{VAT}\left(\mu_{1}>\mu_{2}\right)$

\begin{tabular}{ccccc}
\hline country & $\begin{array}{c}\text { Mean difference of } \\
\text { export of goods and } \\
\text { services (annual \% } \\
\text { growth) before and } \\
\text { after applying VAT }\end{array}$ & $\begin{array}{c}\text { t- } \\
\text { statistic }\end{array}$ & $\begin{array}{c}\text { Sig(2- } \\
\text { tailed) }\end{array}$ & Test Results and Probability \\
\hline Barbados & $\begin{array}{c}5.91000 \\
\text { Chad }\end{array}$ & 2.871 & 0.103 & $\mathrm{H}_{0}$ rejected with 89 \% probability \\
$\mathrm{H}_{0}$ rejected with 87 \% probability
\end{tabular}

Source: Researcher calculations using SPSS software, $\left(\mathrm{H}_{0}\right.$ rejected with less than $90 \%$ probability)

Table 8: Mean Difference of export goods and services (annual \% growth) before and after applying $\operatorname{VAT}\left(\mu_{1}<\mu_{2}\right)$

\begin{tabular}{ccccc}
\hline Country & $\begin{array}{c}\text { mean difference of } \\
\text { export of goods and } \\
\text { services (annual \% } \\
\text { growth)before and } \\
\text { after applying VAT }\end{array}$ & $\begin{array}{c}\text { t- } \\
\text { statistic }\end{array}$ & $\begin{array}{c}\text { Sig(2- } \\
\text { tailed) }\end{array}$ & Test Results and Probability \\
\hline Bulgaria & $-2.46367 \mathrm{E} 1$ & -2.040 & 0.178 & $\mathrm{H}_{0}$ rejected with 82 \% probability \\
Papua New & $-1.67167 \mathrm{E} 1$ & -2.800 & 0.107 & $\mathrm{H}_{0}$ rejected with 89\% probability \\
Guinea & $-1.12300 \mathrm{E} 1$ & -2.181 & 0.161 & $\mathrm{H}_{0}$ rejected with 84 \% probability \\
\hline Serbia & &
\end{tabular}

Source: Researcher calculations using SPSS software, ( $\mathrm{H}_{0}$ rejected with less than $90 \%$ probability) 